\title{
Cellular uptake and toxicity effects of silver nanoparticles in mammalian kidney cells
}

\author{
Mirta Milića, Gerd Leitinger ${ }^{b, c}$, Ivan Pavičića, Maja Zebić Avdičevićd, \\ Slaven Dobrovićd, Walter Goessler ${ }^{\mathrm{e}}$ and Ivana Vinković Vrček ${ }^{\mathrm{a} *}$
}

\begin{abstract}
The rapid progress and early commercial acceptance of silver-based nanomaterials is owed to their biocidal activity. Besides embracing the antimicrobial potential of silver nanoparticles (AgNPs), it is imperative to give special attention to the potential adverse health effects of nanoparticles owing to prolonged exposure. Here, we report a detailed study on the in vitro interactions of citrate-coated AgNPs with porcine kidney (Pk15) cells. As uncertainty remains whether biological/cellular responses to AgNPs are solely as a result of the release of silver ions or whether the AgNPs themselves have toxic effects, we investigated the effects of $\mathrm{Ag}^{+}$on Pk15 cells for comparison. Next, we investigated the cellular uptake of both AgNPs and $\mathrm{Ag}^{+}$in Pk15 cells at various concentrations applied. The detected $\mathrm{Ag}$ contents in cells exposed to 50 mg I AgNPs and $50 \mathrm{mgl}^{-1} \mathrm{Ag}^{+}$were 209 and $25 \mu \mathrm{g}$ of Ag per $10^{6}$ cells, respectively. Transmission electron microscopy (TEM) images indicated that the Pk15 cells internalized AgNPs by endocytosis. Both forms of silver, nano and ionic, decreased the number of viable Pk15 cells after $24 \mathrm{~h}$ in a dose-dependent manner. In spite of a significant uptake into the cells, AgNPs had only insignificant toxicity at concentrations lower than $25 \mathrm{mg} \mathrm{I}^{-1}$, whereas $\mathrm{Ag}^{+}$exhibited a significant decrease in cell viability at one-fifth of this concentration. The Comet assay suggested that a rather high concentration of AgNP (above $25 \mathrm{mg} \mathrm{I}^{-1}$ ) is able to induce genotoxicity in Pk15 cells. Further studies must seek deeper understanding of AgNP behavior in biological media and their interactions with cellular membranes. Copyright $\odot 2014$ John Wiley \& Sons, Ltd.
\end{abstract}

Additional supporting information may be found in the online version of this article at the publisher's web-site.

Keywords: silver nanoparticles; Pk15 cells; absorption; cytotoxicity; genotoxicity

\section{Introduction}

The nanoscience revolution that sprouted throughout the 1990s is becoming a part of our daily life in the form of cosmetics, food packaging, drug delivery systems, therapeutics, biosensors and many others (Nanotechnology Consumer Product Inventory, 2007; Walker and Parsons, 2012). Nanosilver is one of the most commonly used nanomaterials (NMs) with focus on its biocidal activity (Nanotechnology Consumer Product Inventory, 2007; Benn and Westerhoff, 2008; Walker and Parsons, 2012). It is commonly used as a coating or embedding agent for medical purposes: for wound dressings, surgical instruments, implants and bone prostheses (Trop et al., 2006; Cohen et al., 2007). Nanosilver coatings are also used for manufacturing odor-resistant textiles (Vigneshwaran et al., 2007; Benn and Westerhoff, 2008). Furthermore, nanosilver is marketed as deodorants, room sprays, water cleaners, laundry detergents, in food packaging and wall paints (Lee et al., 2007; Zhang and Sun, 2007). The increasing use of nanosilver-containing products poses toxicological and environmental issues which need to be addressed. The environmental impact of NMs is expected to increase substantially in the future. In spite of numerous and extensive reports on the potential applications and benefits of AgNPs, there is a lack of information concerning the health implications of exposure during manufacturing and handling processes as well as during household applications of nanosilver-based materials.

Recent studies suggested that NMs could easily enter into the human body (AshaRani et al., 2009; Dziendzikowska et al., 2012; Walker and Parsons, 2012; Wang et al., 2012). Because of their nano-scale dimension - NPs are of a similar size to typical cellular components and proteins - NPs may bypass natural mechanical barriers, possibly leading to adverse tissue reactions (De Lima et al., 2012). As a result, the particles might be taken up into cells. Generally, NPs of different physical and chemical properties may enter the cells by different mechanisms, such as phagocytosis, macropinocytosis, endocytosis, or directly by so-called adhesive interactions (Brandenberger et al., 2010). A large specific surface area is one of the important properties of the cytotoxic activity of nanoparticles (Rabolli et al., 2011; Fraga et al., 2013). However, even although NPs display a

*Correspondence to: I. Vinković Vrček, Institute for Medical Research and Occupational Health, Ksaverska cesta 2, Zagreb, Croatia. Email: ivinkovic@imi.hr

${ }^{a}$ Institute for Medical Research and Occupational Health, Ksaverska cesta 2, 10 000 Zagreb, Croatia

${ }^{b}$ Research Unit Electron Microscopic Techniques, Institute of Cell Biology, Histology and Embryology, Centre for Molecular Medicine (ZMM), Medical University of Graz, Harrachgasse 21, 8010 Graz, Austria

'Core Facility Ultrastructure Analysis, Centre for Medical Research (ZMF), Medical University of Graz, Stiftingtalstrasse 24, 8010 Graz, Austria

${ }^{d}$ University of Zagreb, Faculty for Naval Architecture and Civil Engineering, Ivana Lučića 5, 10000 Zagreb, Croatia

${ }^{e}$ Institute for Chemistry, Karl-Franzens University, Universitatesplatz 1, 8010 Graz, Austria 
certain size after synthesis, they might aggregate into different shapes and sizes during the in vitro and in vivo studies. In contrast, partial oxidation of AgNPs may lead to the slow release of $\mathrm{Ag}^{+}$(Lok et al., 2007; Liu and Hurt, 2010), which is known as one of the most toxic forms of this heavy metal.

In order to understand and interpret the exact cellular influences of NPs, a thorough characterization of individual nanoparticles is necessary. Whether or not metallic NPs will be modified in vitro depends on the $\mathrm{pH}$, ionic strength, thermodynamic feasibility, concentration of the species, kinetic facility of electron transfers and also redox conditions of the biological media (Schoonen et al., 2006). The oxidation or reduction processes can lead to the release of ions in solution but redox reactions can also occur at the surface of NPs leading to a change in the crystalline nature. Both of these phenomena can occur separately or simultaneously. The driving force for dissolution depends on the metal solubility within a given environment as well as the concentration gradient between the particle surface and the bulk solution phase (Liu and Hurt, 2010). Dissolution may be a critical step in determining the fate of some metallic NPs in the environment and within the organisms. As such, a careful assessment of the physicochemical properties of the NPs at the time that they are initially administered should be carried out as a part of any complete nanotoxicology study.

In spite of the rapid increase in manufacture and utilization of AgNP, the potential for adverse health effects owing to prolonged exposure at various concentration levels in living organisms and the environment has not yet been established. The in vitro toxicity of AgNPs has been evaluated in a wide range of studies but there is still a lack of consistent and reliable data. There is thus a requirement of more research coherence for obtaining meaningful data. Here, we made an effort to understand in vitro nanotoxicity by studying the effect of highly purified and well-characterized citrate-coated AgNPs on porcine kidney (Pk15) cells. The selection of cell types representing the target tissue is distinctively important. It has been shown that AgNPs, upon reaching the blood circulation, can be further distributed to other organs, or become metabolized in the liver and kidney (Walker and Parsons, 2012). The normal tissue turnover in these organs is very slow, so any silver that may be deposited therein is likely to persist for long periods. In the investigation of subchronic AgNP toxicity in Sprague-Dawley rats, Kim et al. (2008) have shown liver damages by histopathological evaluation but no significant function or histopathologic changes in kidneys. Therefore, the Pk15 cell line was selected as representative of normal mammalian kidney cells. For toxicity evaluations, Pk15 cell viability and DNA damage were assessed under exposed conditions. Next we investigated the cellular uptake and intracellular localization of AgNPs. Particular attention was also given to the properties and stability of the AgNPs in a cell growth medium by analysis of agglomeration and the released $\mathrm{Ag}^{+}$fraction.

\section{Materials and Methods}

\section{Chemicals}

(3-(4,5-dimethylthiazolyl-2)-2,5-diphenyltetrazolium bromide (MTT) and Bradford solution were from Sigma Chemical Company (St. Louis, MO, USA). Roswell Park Memorial Institute (RPMI)-1640
Medium, fetal bovine serum (FBS) and penicillin-streptomycin solution were purchased from Invitrogen (Carlsbad, CA, USA). Nicotinamide adenine dinucleotide phosphate disodium salt $\left(\mathrm{NADP}^{+}\right)$and nicotinamide adenine dinucleotide phosphatereduced tetrasodium salt (NADPH) were from Merck (Darmstadt, Germany). The plastic and glassware used for chemical analysis and cell culturing were from Sarstedt (Belgium). Osmium tetroxide was purchased from Agar Scientific (Stansted, UK) and TAAB epoxy resin (medium hard) from Aldermaston (Berkshire, UK). All other analytical grade chemicals were obtained from Sigma (St. Louis) and Merck (Darmstadt, Germany) chemical companies. All dilutions were made with ultrapure water $(18.2 \mathrm{M} \Omega \mathrm{cm})$, obtained from a GenPure UltraPure water system (GenPure UV; TKA Wasseraufbereitungssysteme GmbH, Niederelbert, Germany).

\section{Synthesis and Stability Evaluation of AgNPs}

Citrate-coated AgNPs were synthesized according to the method described by Lee and Meisel (1982). Briefly, a sample of silver nitrate $(0.045 \mathrm{~g})$ was suspended in ultrapure water $\left(250 \mathrm{ml}, 45^{\circ} \mathrm{C}\right)$ and heated to boiling under rapid stirring. Immediately after boiling commenced, $5 \mathrm{ml}$ of $1 \%$ sodium citrate was added rapidly. The solution was kept at $80^{\circ} \mathrm{C}$ for $90 \mathrm{~min}$ with continuous stirring. In order to prepare purified and stable AgNPs, the freshly prepared NP suspensions were washed twice immediately after synthesis with ultrapure water (UPW) using centrifugation at $15790 \mathrm{~g}$ for $20 \mathrm{~min}$. The washed AgNPs were resuspended in UPW using ultrasound, and stored in the dark at $4{ }^{\circ} \mathrm{C}$ until use. By removing chemicals from the AgNP suspension, the ionic strength of the solution was decreased, leading to an increase in the thickness of the electrical double layer on the surface of the AgNPs (Cañamares et al., 2008). Therefore, the washed AgNPs were stable in UPW for months (Cañamares et al., 2008). Total silver concentrations in AgNP colloidal suspensions were determined in acidified solutions $\left(10 \% \mathrm{HNO}_{3}\right)$ using an Agilent Technologies $7500 \mathrm{cx}$ inductively coupled plasma mass spectrometer (ICPMS) (Agilent, Waldbronn, Germany). Prior to the ICPMS measurements, the AgNP suspensions were digested with $\mathrm{HNO}_{3}$ in closed-vessels with the UltraCLAVE IV Milestone digestion device (MLS GmbH Mikrowellen-Laborsysteme, Leutkirch, Germany). A silver standard solution (1000 mgl-1 in $5 \% \mathrm{HNO}_{3}$ ) from Merck was used for calibration.

The formation of nano-sized silver particles was verified by the presence of a Surface Plasmon Resonance (SPR) peak measured using a UV-Vis spectrophotometer (CARY 300; Varian Inc., Sydney, Australia). AgNPs were characterized at two different concentrations ( 1 and $10 \mathrm{mgl}^{-1}$ ) under different experimental conditions, i.e. in UPW and in cell-free culture medium (CCM). The aim was to ascertain whether there is a time-dependent agglomeration of NPs after various incubation times and in different suspensions, as agglomerated NPs have different properties from those in monodisperse form.

The size and charge of AgNPs were measured using Zetasizer Nano ZS (Malvern, UK) equipped with green laser $(532 \mathrm{~nm})$. The intensity of scattered light was detected at the angle of $173^{\circ}$. All measurements were conducted at $25^{\circ} \mathrm{C}$. The data processing was done by Zetasizer software 6.32 (Malvern instruments). Results are reported as an average value of 10 measurements and the size distributions are reported as volume distributions (Supporting Information, Fig. S1). The charge of AgNPs was 
evaluated by measuring the electrophoretic $\zeta$-potential of AgNPs. Results are reported as an average value of five measurements. In addition, synthesized and purified AgNPs were visualized using a transmission electron microscope (TEM; Zeiss 902A). The microscope was operated in bright field mode at an acceleration voltage of $80 \mathrm{kV}$. Images were recorded with Canon PowerShot S50 camera attached to the microscope. TEM samples were prepared by depositing a drop of the sample suspension on a formavar-coated copper grid. Samples were air-dried at room temperature.

The possible silver dissolution in UPW and CCM was determined by tracking the appearance of dissolved silver ions using the Orion 9616BNWP Sure-Flow ${ }^{\text {Tm }}$ Combination Silver/Sulfide Electrode (Thermo Scientific, Waltham, USA) connected to a Seven Easy ISE meter (Mettler-Toledo, Greifensee, Switzerland) over $24 \mathrm{~h}$. The electrode was preconditioned before each experiment by immersion in a solution containing $0.01 \mathrm{moll}^{-1} \mathrm{Ag}^{+}$for $3 \mathrm{~h}$. Silver stock solutions were prepared in UPW from reagent grade silver nitrate without further purification. Four calibration standards that bracket the expected sample concentration were prepared from a $10 \mathrm{mg} \mathrm{I}^{-1}$ silver standard. Linear calibration was obtained over the whole range with a slope of $59.3 \mathrm{mV} / \mathrm{log}[\mathrm{Ag}+]$. For measurements in AgNP suspensions, dilutions of the original suspension $\left(2.8 \mathrm{mmoll}^{-1} \mathrm{Ag}\right.$ ) were prepared in the range $1: 10$ to $1: 100$. Concentrations of $\mathrm{Ag}^{+}$were calculated from the obtained potential using the linear calibration line.

\section{Cell Culture and Treatment Protocols}

Pk15 cells were maintained in RPMI medium, supplemented with $10 \%(\mathrm{v} / \mathrm{v}) \mathrm{FBS}, 20 \mathrm{IU} \mathrm{ml}^{-1}$ penicillin and $20 \mathrm{mgl}^{-1}$ streptomycin. The cells were seeded in 6-, 12- or 96-well plates or cultured flasks and maintained at $37{ }^{\circ} \mathrm{C}$ in a humidified atmosphere of $5 \% \mathrm{CO}_{2}$ in air. The medium was replaced every 2-3 days. Upon reaching $70 \%$ adherent confluence, the cells were treated with a range of concentrations of AgNPs.

In each experiment, stock AgNP suspensions were sonicated and freshly diluted to appropriate concentrations in the cell medium. In addition, cells were exposed to several different concentrations of $\mathrm{Ag}^{+}$(in the form of $\mathrm{AgNO}_{3}$ ) in order to evaluate the contribution of $\mathrm{Ag}^{+}$to the toxicity of AgNPs. Control cells without treatment were performed for each analysis. At the end of the exposure period, the toxicity end points were evaluated in the control and exposed cells.

\section{Uptake of AgNP}

The uptake of AgNPs to Pk15 cells was examined by inductively coupled plasma mass spectrometry (ICPMS) and visualized by TEM. The cells were seeded in six-well tissue culture plates (at a density of $2 \times 10^{6}$ cells per $\mathrm{ml}$ growth medium/well) and exposed to an ionic or nanoparticulate form of silver. Control cells were incubated with ultrapure water (added in the amount which corresponds to volumes of $\mathrm{AgNP}$ or $\mathrm{Ag}^{+}$stock suspensions added to the cell medium) and in normal cell medium (RPMI supplemented with 10\% FBS and antibiotics). After a treatment period of $24 \mathrm{~h}$, the medium was removed and the adherent cells were washed several times with phosphate-buffered saline (PBS) solution, and then detached from the culture plates by adding $1 \mathrm{ml}$ of $0.25 \%$ enzyme trypsin for $3 \mathrm{~min}$ at $37^{\circ} \mathrm{C}$. Subsequently, the cells were washed with PBS ( $\mathrm{pH} 7.4)$ and collected for ICPMS and TEM analyzes.

In the case of ICPMS quantification of total Ag absorbed by the cells, the cells were centrifuged at $1500 \mathrm{~g}$ for $10 \mathrm{~min}$ at $4{ }^{\circ} \mathrm{C}$, and cell number was counted. The harvested cells were digested in closed-vessels with the UltraCLAVE IV Milestone digestion device (MLS GmbH Mikrowellen-Laborsysteme, Leutkirch, Germany) with a modified US EPA method 3052. Briefly, 5-ml concentrated $\mathrm{HNO}_{3}$ was added into the obtained buffer phase and the mixture was irradiated at $120^{\circ} \mathrm{C}(800 \mathrm{~W})$ for $10 \mathrm{~min}$, followed by $180^{\circ} \mathrm{C}(1600 \mathrm{~W})$ for $30 \mathrm{~min}$. After digestion, samples were diluted with water to $50 \mathrm{ml}$ and stored at $4{ }^{\circ} \mathrm{C}$ for further analysis. The uptake of $\mathrm{Ag}^{+}$or AgNP by cells was quantified by measuring the total $\mathrm{Ag}$ contents in the digested samples using an Agilent Technologies 7500cx ICPMS (Agilent). A silver standard solution ( $1000 \mathrm{mgl}^{-1}$ in $5 \% \mathrm{HNO}_{3}$ ) from Merck was used for calibration.

In order to visualize AgNPs inside the Pk15 cells by TEM, the specimens were fixed in $2.5 \%$ glutaraldehyde in $0.1 \mathrm{moll}^{-1}$ sodium phosphate buffer, $\mathrm{pH}$ 7.4. After rinsing in the same buffer, the specimens were post fixed in $2 \%$ osmium tetraoxide in the same buffer for $30 \mathrm{~min}$. All the specimens were then dehydrated in a series of graded alcohols, and embedded in TAAB embedding resin (TAAB, Aldermaston, UK). After sectioning on a Leica UC6 ultramicrotome (Leica Microsystems, Vienna, Austria) using a Diatome diamond knife (Ultra 45; Diatome, Biel, Switzerland), they were contrasted using uranyl acetate and lead citrate.

Images were made at $120 \mathrm{kV}$ FEl Tecnai $\mathrm{G}^{2} 20$ TEM (FEI Europe B.V., Eindhoven, The Netherlands), for bright field a Gatan Ultrascan 1000 CCTV camera was used whereas for TEM, a High Angle Annular Darkfield (HAADF detector) was used. Scanning transmission electron microscopy (STEM) was done with the same microscope, using a high angle annular dark field detector. Acceleration voltage was $120 \mathrm{kV}$. X-ray spectroscopy was performed with an EDAX Silicium type ultrathin unit (SUTW) Detector.

A control protocol in which the osmium tetroxide step was omitted to detect the possible loss of AgNPs during osmium tetraoxide treatment (Leitinger et al., 2000) showed that AgNPs were present in the sections regardless of the treatment with osmium tetraoxide.

\section{Cell Viability Assays}

Cell viability was determined by the MTT assay (Mosmann, 1983) based on the cleavage of the tetrazolium salt by metabolically active cells to form a water-insoluble formazan dye. Cells were seeded in 96 -well tissue culture plates $\left(10^{4}\right.$ cells per $200 \mu \mathrm{l}$ growth medium/well) followed by an overnight incubation. Citrate-coated AgNPs were added to quintuplicate wells to a final concentration range of 0 to $100 \mathrm{mgl}^{-1}$ and incubated for another $24 \mathrm{~h}$. For comparison, cells were also treated with $\mathrm{AgNO}_{3}$ in a concentration range of $0-1 \mathrm{mgl}^{-1}$. Control cells were incubated with ultrapure water (added in the amount which corresponds to volumes of AgNP or $\mathrm{Ag}^{+}$stock suspensions added to the cell medium) and in normal cell medium (RPMI supplemented with $10 \%$ FBS and antibiotics). At the end of the treatment, the cells were washed with $200 \mu \mathrm{l}$ PBS/well and then 
$100 \mu$ l of diluted MTT in RPMI medium was added to each well to obtain the final concentration of $5 \mathrm{mg} \mathrm{ml}^{-1}$. After $4 \mathrm{~h}$ of incubation at $37^{\circ} \mathrm{C}$, the MTT solution from each well was removed by aspiration. This procedure is used for the reduction of MTT by metabolically active cells, in part by the action of dehydrogenase enzymes, to generate reducing equivalents such as NADH and NADPH. After the reduction, $100 \mu$ of isopropanol was added to the wells and the plates were placed on a shaker for $15 \mathrm{~min}$ to dissolve formazan crystals. The optical density at $595 \mathrm{~nm}$, for each well, was then determined using a Victor ${ }^{\text {TM }}$ multilabel reader (PerkinElmer, Walthman, MA, USA). Concentrations of AgNP or $\mathrm{AgNO}_{3}$ showing a $50 \%$ reduction in cell viability [half maximal inhibitory concentration $\left(\mathrm{IC}_{50}\right)$ values] were then calculated. Socalled zero values were calculated from the cells exposed only to treatment with ultrapure water, as a dissolvent for AgNPs.

\section{Interferences of Nanoparticles With Cell Viability Assay}

The effects of ionic or nano form of silver on the reduction rate of $\mathrm{MTT}$ to formazan were determined by incubating MTT with different concentrations of $\mathrm{Ag}^{+}$and $\mathrm{AgNP}$ at $37^{\circ} \mathrm{C}$ for $3 \mathrm{~h}$ and measuring the formazan concentration afterwards. Final concentration ranges of $\mathrm{AgNP}$ and $\mathrm{AgNO}_{3}$ were $0-100$ and $0-1 \mathrm{mgl}^{-1}$, respectively. A total of $50 \mu$ l of isopropanol was added and the samples were shaken to dissolve formazan crystals and incubated for another $10 \mathrm{~min}$ at $37^{\circ} \mathrm{C}$. The mixture was centrifuged at $115 \mathrm{~g}$ for $10 \mathrm{~min}$ and the supernatant was placed in 96-well plates. The absorbance at $595 \mathrm{~nm}$, for each well, was then determined using a Victor ${ }^{\text {Tm }}$ multilabel reader (PerkinElmer). Control experiments without silver were done in each case. Results were expressed as \% of formazan concentration in the control sample.

\section{Comet Assay}

DNA damage can be detected by the use of a comet assay. Single cell gel electrophoresis (or comet assay) is a well-known technique for the evaluation of primary DNA damage on the level of single cell in both in vitro and in vivo conditions (Singh et al., 1988; Tice et al., 2000). It is also well known for its high reproducibility, sensitivity and rapid results. After the lysis of cell membrane and denaturation step, the released DNA can form a shape of a comet during electrophoresis if there are damaged fragments that can travel by the influence of current, as DNA by itself is too large to pass through the pores of a gel agarosis in which it has been kept. Cells were seeded in 24-well plates $\left(10^{4}-10^{5}\right.$ cells per $\left.\mathrm{ml}\right)$ and treated with $1 \mathrm{mgl}^{-1} \mathrm{AgNO}_{3}$ and AgNPs in the concentration range from 1 to $75 \mathrm{mgl}^{-1}$ for 24 and $48 \mathrm{~h}$. Prior to treatment, the cells were incubated in serum-free media for $12 \mathrm{~h}$ (in order to obtain cells in the same cell cycle phase). Control cells were incubated with ultrapure water (added in the amount which corresponds to volumes of AgNP or $\mathrm{Ag}^{+}$stock suspensions added to the cell medium) and in normal cell medium (RPMI supplemented with 10\% FBS and antibiotics).

After the treatment, cells were detached by the use of $1 \mathrm{ml}$ of trypsin and resuspended in $300 \mu$ of whole RPMI medium with FBS included (1:1) for trypsin deactivation. A single-cell suspension was centrifuged at $70 \mathrm{~g}$ for $8 \mathrm{~min}$. The supernatant was removed and $100 \mu \mathrm{l}$ of whole RPMI medium was added.
Aliquots of $10 \mu \mathrm{l}$ of this suspension were mixed with $100 \mu \mathrm{l}$ of $0.5 \%$ low-melting agarose and the suspension was placed on slides precoated with $200 \mu \mathrm{l}$ of $1 \%$ normal-melting agarose. Slides were allowed to solidify on ice for $10 \mathrm{~min}$ and were kept in prechilled lysis solution $\left(2.5 \mathrm{moll}^{-1} \mathrm{NaCl}, 100 \mathrm{mmoll}-1\right.$ $\mathrm{Na}_{2}$ EDTA, $10 \mathrm{mmol}^{-1}$ Tris, $\mathrm{pH}=10,1 \%$ sodium sarcosinate, $1 \%$ Triton X-100, $10 \%$ dimethyl sulfoxide) at $4{ }^{\circ} \mathrm{C}$. After $1 \mathrm{~h}$, the slides were placed in freshly prepared denaturation and electrophoresis buffer (10 mmoll ${ }^{-1} \mathrm{NaOH}, 200 \mathrm{mmoll}^{-1} \mathrm{Na}_{2}$ EDTA, $\left.\mathrm{pH}=13\right)$, incubated for $20 \mathrm{~min}$ at $4{ }^{\circ} \mathrm{C}$ and electrophoresed for $20 \mathrm{~min}$ at $25 \mathrm{~V}$ and $300 \mathrm{~mA}$. Finally, the slides were neutralized three times, 5 min each time, in $0.4 \mathrm{moll}^{-1}$ Tris buffer $(\mathrm{pH} 7.5)$ and then dehydrated with ethanol (2 times with $70 \%$ and once with $96 \%$ ethanol, for $10 \mathrm{~min}$ each time). The slides were kept in a humid atmosphere in the dark at $4{ }^{\circ} \mathrm{C}$ until further analysis.

For image analysis, slides were stained with $100 \mu \mathrm{l}$ of $20 \mu \mathrm{g} \mathrm{ml}^{-1}$ ethidium bromide solution for $10 \mathrm{~min}$. A minimum of 100 randomly selected DNA per sample (50 comets per slide) was scored. Comets were randomly captured at a constant depth of the gel, avoiding the edges of the gel, occasional dead cells, and DNA near or trapped in an air bubble and superimposed comets. Slides were scored using an image analysis system (Comet Assay II; Perceptive Instruments Ltd, Bury St Edmunds, UK) attached to a fluorescence microscope (Zeiss, Jena, Germany), equipped with the appropriate filters. The parameters selected for the quantification of DNA damage were: a comet tail length (in $\mu \mathrm{m}$ ) and tail intensity (\% DNA). The extent of DNA damage, as recorded by the alkaline comet assay, was analyzed considering the mean ( \pm standard deviation of the mean), median and range of the comet parameters measured.

\section{Statistical Analysis}

Differences between treatments for the different measured variables were tested using the Mann-Whitney U-test, one-way analysis of variance (ANOVA) with the post-hoc Scheffé test and Pearson's $\chi^{2}$ test. In other cases, differences were tested using the Dunnett test (to assess differences versus a control), or Kruskal-Wallis ANOvA of ranks (non-parametric test used when assumptions of homogeneity of variances were not reachable). The minimal significance level was $P<0.05$. All statistical analyzes were computed using Statistica 10.0 (Statsoft, Inc., Tulsa, OK, USA).

\section{Results and Discussion}

\section{Characterization and Stability Evaluation of AgNPs}

The preparation of stable nanoparticle medium dispersions is essential for biological examinations of NPs. Stable NPs produced in the laboratory may become unstable when dispersed in different media. Generally, in vitro examinations require dispersing NPs into the culture medium. The cell culture medium includes several amounts of salts, proteins, amino acids and vitamins as nutrients of cells, and dispersed NPs may form various sizes of secondary particles. When an unstable and non-uniform dispersion is applied to adherent cells, the large secondary particles reach the cells faster than nanoscale secondary particles (Hinderliter et al., 2010). Moreover, large secondary 
particles accumulated on the cells may prevent the contact of small secondary particles and the cells. In order to draw valid conclusions from the evaluation of the cellular influences of NPs, comprehensive information on the characteristics and stability of nanoparticle medium dispersion is important. Physical parameters such as surface area, particle size, surface charge and zeta potential are very important for providing mechanistic details in the uptake, persistence and biological toxicity of NPs inside living cells (Yang et al., 2009; Fraga et al., 2013). Particle size may be a critical parameter for NP bioactivity, but it is difficult to ascertain which parameter plays an essential role in the biological effects when comparing various types of nanoparticles with different shapes and composition (Yang et al., 2009).

Characterization of purified AgNPs was performed in both UPW and CCM using the dynamic light scattering (DLS) method, UV-Vis spectroscopy, TEM and silver-ion selective electrode (Ag-ISE) measurements. A SPR peak at $419 \mathrm{~nm}$ in UV-VIS spectra confirmed a nanoparticulate form of purified AgNP in UPW. Table 1 summarizes data for hydrodynamic diameter (HDD), polydispersity index (PDI) values, $\zeta$ potential values and the amount of the released $\mathrm{Ag}^{+}$. DLS measurements of AgNPs in UPW showed that the volume size distribution is bimodal (Supporting Information, Fig. S1), with larger particles, i.e. $61.2 \pm 33.9 \mathrm{~nm}$, being dominant (see Table 1). The $\zeta$ potential value of $-39.8 \pm 3.4 \mathrm{mV}$ indicates electrostatic stabilization of AgNPs owing to the ionization of the polar citrate carboxyl groups on the surface of NPs. The TEM analysis (Fig. 1A and Fig S2 in Supporting Information) confirmed these results and also revealed the presence of non-uniformly shaped NPs.

In the present study, we carefully addressed changes in agglomeration, an aspect often completely overlooked in studies within the field of toxicology. Thus, the aggregation behavior of the AgNPs was demonstrated upon suspension in CCM, also seen from the TEM investigation (Fig. 1B). From the colloidal chemistry point of view, CCM is a complex media where different interactions at the nanoscale could be expected. Aggregation of citrate-coated AgNPs could be explained by the displacement of electrostatically weakly bound citrate with components of the RPMI medium, triggered by the high ionic strength of the medium. In terms of volume, $71 \%$ of the AgNPs in CCM were within $405.4 \pm 143.9 \mathrm{~nm}$, whereas $29 \%$ were within $189.9 \pm 51.3 \mathrm{~nm}$ (Table 1 ). The $\zeta$ potential value of $-18.8 \pm 5.8 \mathrm{mV}$

Table 1. Characteristics and stability parameters [size by means of hydrodynamic diameter (HDD) and mean volume, polydispersity index (PDI) values, $\zeta$ potential values and percentage of released $\mathrm{Ag}^{+}$] of citrate-coated silver nanoparticles (AgNPs) in ultrapure water (UPW) and in cell-free culture medium (CCM) after $24 \mathrm{~h}$

\begin{tabular}{|c|c|c|c|c|}
\hline \multirow{2}{*}{\multicolumn{3}{|c|}{ Characteristics }} & \multicolumn{2}{|c|}{ Medium } \\
\hline & & & UPW & CCM \\
\hline \multirow[t]{7}{*}{ Size } & Peak I & $\mathrm{HDD}, \mathrm{nm}$ & $61.2 \pm 33.9$ & $405.4 \pm 143.9$ \\
\hline & & Mean volume & $82.4 \%$ & $71.3 \%$ \\
\hline & Peak II & HDD, nm & $13.8 \pm 4.9$ & $189.9 \pm 51.3$ \\
\hline & & Mean volume & $17.6 \%$ & $28.7 \%$ \\
\hline & & DI & 0.176 & 0.478 \\
\hline & $\zeta$ pote & ntial, mV & $-39.8 \pm 3.4$ & $-18.8 \pm 5.8$ \\
\hline & eleased & $\mathrm{Ag}^{+}, \mathrm{mg} \mathrm{I}^{-1}$ & $1.1 \%$ & $0.4 \%$ \\
\hline
\end{tabular}

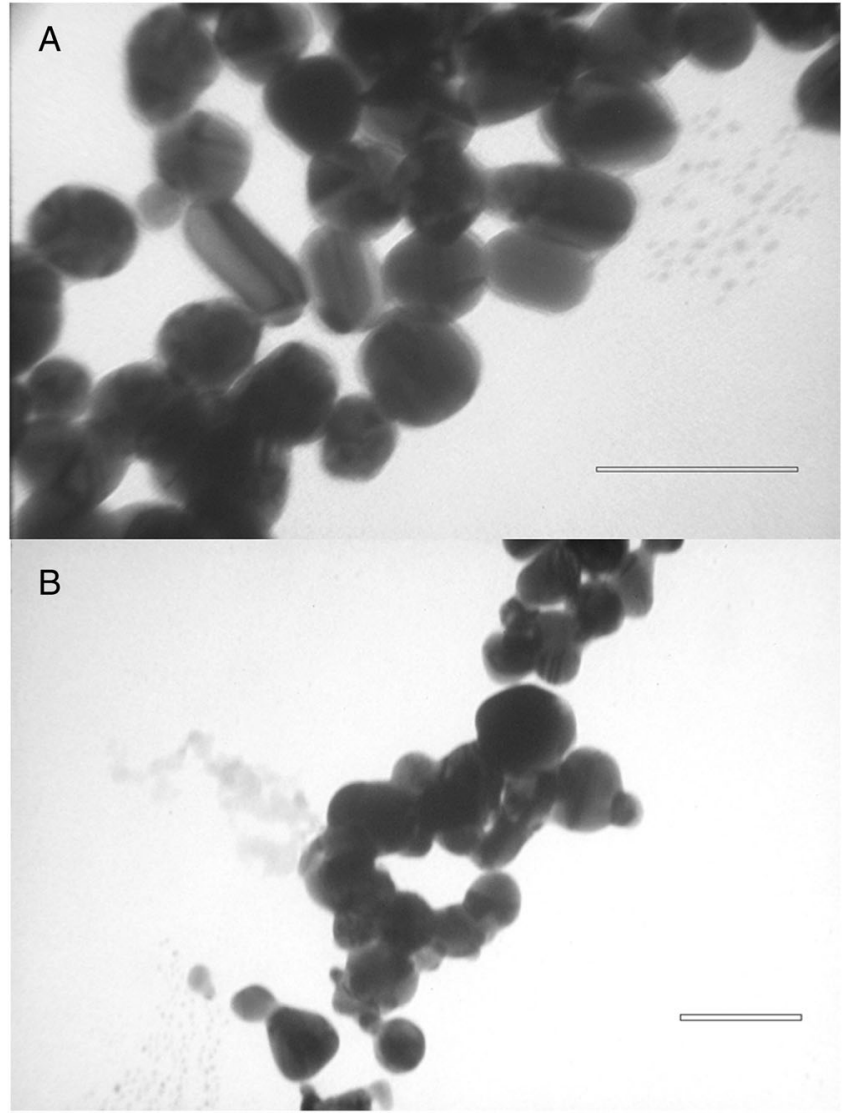

Figure 1. Transmission electron microscopy (TEM) micrographs of citrate-coated silver nanoparticles (AgNPs) in (A) ultrapure water and (B) cell-free culture medium [RPMI medium, supplemented with $10 \%(\mathrm{v} / \mathrm{v})$ fetal bovine serum (FBS), $20 \mathrm{IU} \mathrm{ml}^{-1}$ penicillin and $20 \mathrm{mg} \mathrm{I}^{-1}$ streptomycin] after $24 \mathrm{~h}$. Scale bars represent $100 \mathrm{~nm}$.

also indicated AgNP impaired stability in the CCM (Table 1). The increase in $\zeta$ potential value can be ascribed to the adsorption of media molecules of the CCM on the particle surfaces quenching the charge and simultaneously providing steric repulsion towards pronounced aggregation (content of larger particles is higher) in CCM compared with UPW. The TEM results were in accordance with DLS measurements showing particles organized in nanometric, but also in micrometric agglomerates (Fig. 1B). However, single nanoparticles were also detected.

In order to estimate the stability of AgNPs regarding the release of $\mathrm{Ag}^{+}$ions, we investigated the degree of NP dissolution using two different methods: Ag-ISE and centrifugal ultrafiltration. The dissolution of AgNP is a complicated process affected by factors such as the particle size, the surface functionalization and the nature of the immersion medium (Christian et al., 2008; Auffan et al., 2009). It is still unclear whether the toxicity of AgNPs is only because of dissolved $\mathrm{Ag}^{+}$or if the AgNPs themselves show a toxic effect (Auffan et al., 2009; Powers et al., 2011; Sahu et al., 2014). Using the Ag-ISE, free $\mathrm{Ag}^{+}$was determined to be $1.1 \%$ of the total $\mathrm{Ag}$ in AgNPs suspended in the UPW, whereas maximum concentrations of labile Ag present in the AgNP suspended in CCM were less than $0.4 \%$ of the total Ag (Table 1). The reason for differences in free $\mathrm{Ag}^{+}$content in the CCM compared with the UPW may be the underestimation of the total amount of $\mathrm{Ag}$ owing to the complexation processes between $\mathrm{Ag}^{+}$and macromolecules present in the CCM or 
precipitation of silver salts (chloride or phosphate) in the CCM. Another possible reason for the decrease of $\mathrm{Ag}+$ release in the CCM compared with the UPW may be because of the decrease in the surface area of AgNPs that resulted from their aggregation in the CCM.

\section{AgNPs Uptake and Distribution in Pk15 Cells}

As a result of the small dimension of AgNPs, there is concern about their possible penetration into organisms, their accumulation in cells and possible toxic effects. Several previous studies have reported the uptake of AgNPs in different cell lines (Farkas et al., 2011; Liu et al., 2010; Behra et al., 2013; McShan et al., 2014). In vivo biodistribution studies have shown that the main target organs for AgNP accumulation are the liver, spleen, lung, kidneys and brain (Walker and Parsons, 2012). Very recently, Castellini et al. (2014) have demonstrated that AgNPs may also pass the blood-testis barrier compromising male gametes. The primary target organ seemed to be the liver, but a recent study (Dziendzikowska et al., 2012) showed that the concentration of silver in the kidneys increased during rat exposure to AgNPs being the highest 28 days after the injection. Dziendzikowska et al. (2012) also found very low urine excretion of silver indicating that AgNPs accumulate in the kidneys. Therefore, we selected the Pk15 cell line as representative of normal mammalian kidney cells. We examined the accumulation of both AgNPs and $\mathrm{Ag}^{+}$in Pk15 cells at various concentrations applied. The amount of silver taken up by the cells was determined after $24 \mathrm{~h}$ by measuring the total silver content in digested cells using ICPMS. Both AgNPs and Ag + were efficiently taken up in a concentration-dependent manner by $\mathrm{Pk} 15$ cells, but the Ag level was only $1 / 10^{\text {th }}$ of that found for AgNPs (Fig. 2): detected $\mathrm{Ag}$ contents in cells exposed to $50 \mathrm{mgl}^{-1}$ AgNPs and $\mathrm{Ag}^{+}$were 209 and $25 \mu \mathrm{g}$ of $\mathrm{Ag}$ per $10^{6}$ cells, respectively. A similar observation for nanoparticle interaction with human epithelial cells was reported by Wang et al. (2012) and Cronholm et al. (2013). On the contrary, other previous studies have shown that the cells adsorbed a higher amount of silver when exposed to $\mathrm{Ag}^{+}$in comparison to cells exposed to AgNPs at the same exposure doses (Liu et al., 2010; Farkas et al., 2011). The reason may stem from the more pronounced endocytosis function of Pk15 and similar human epithelial cells compared with cells used in these studies (Liu et al., 2010; Farkas et al., 2011). Indeed, several authors have suggested that endocytosis is a major pathway of NP uptake by cells, whereas transport proteins are responsible for the efficient pass of metallic ions through the cell membrane (Wang et al., 2012). In the ionic form, Ag can be taken up by transporters, because its properties are most similar to $\mathrm{Na}^{+}$and $\mathrm{Cu}^{+}$ ions (Behra et al., 2013). Notably, some of Cu transporter proteins have been shown to transport Ag as well as Cu (Behra et al., 2013). The strong inhibition by $\mathrm{Ag}^{+}$in $\mathrm{Cu}$ uptake experiments suggests that $\mathrm{Ag}^{+}$, which are isoelectric to $\mathrm{Cu}^{+}$, can be taken up by the same high-affinity Cu transporter (CTR1) (Lee et al., 2002). The CTR1-independent $\mathrm{Ag}$ and $\mathrm{Cu}$ uptake is well known from the fish physiology literature (Bury and Wood, 1999). Unlike CTR1mediated $\mathrm{Cu}^{+}$uptake, the CTR1-independent $\mathrm{Cu}^{2+}$ transport activity appears to be via the sodium channel (ENaC) located at the apical membrane of polarized epithelial cells or the basolateral $\mathrm{Na}^{+} / \mathrm{K}^{+}$-ATPase (Bury and Wood, 1999). This uptake route for $\mathrm{Cu}$ and $\mathrm{Ag}$ is likely to occur only in the freshwater fish,

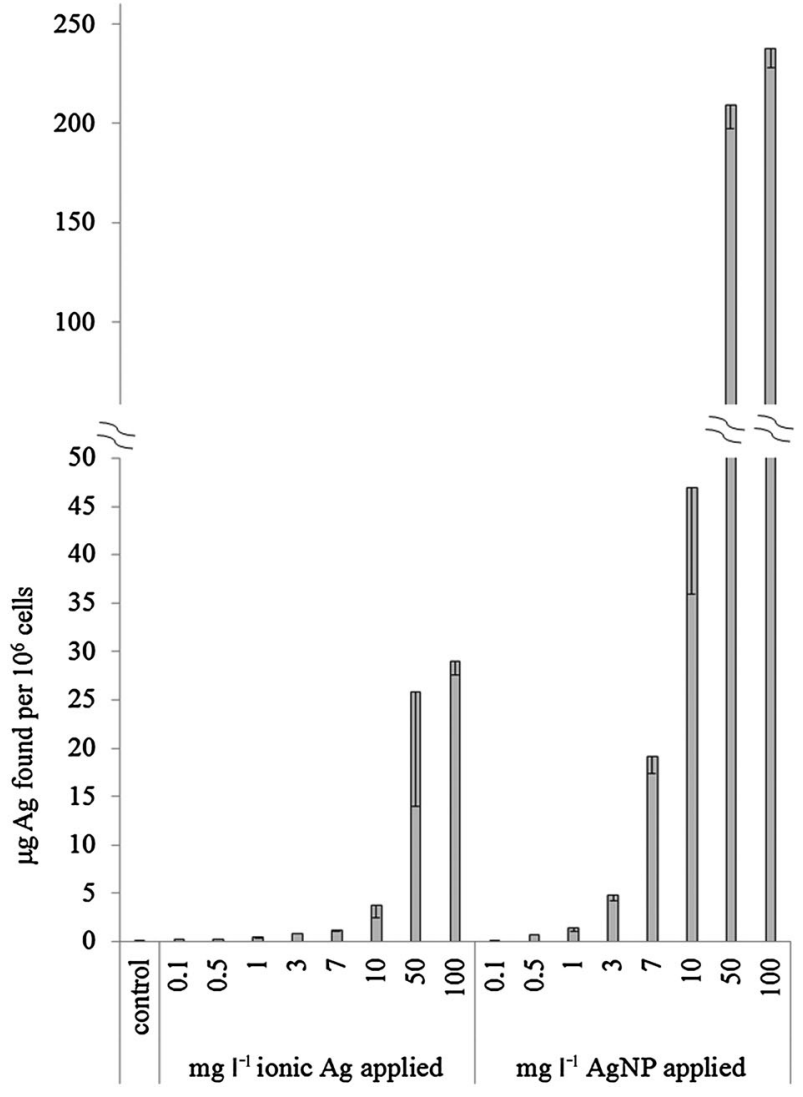

Figure 2. Uptake of the silver nanoparticles (AgNPs) and $\mathrm{Ag}^{+}$in $\mathrm{Pk} 15$ cells. Intracellular Ag content (in $\mu \mathrm{g}$ per $10^{6}$ cells) was determined by Inductively Coupled Plasma Mass Spectrometry (ICP-MS) in digested Pk15 cells treated with various concentrations of citrate-coated AgNPs and $\mathrm{AgNO}_{3}$. Data are expressed as the mean of five replicates and error bars represent standard deviations.

where external $\mathrm{Na}^{+}$is only a few millimolar or less (Behra et al., 2013). Because of their size, AgNPs could not be transported across $\mathrm{Cu}$ transporters. Therefore, any possible interaction of CTR1 with AgNPs would be with $\mathrm{Ag}^{+}$dissolved from the NP possibly inside the acidic environment of endosomes or lysosomes (Behra et al., 2013). The internalization of negatively charged NPs is thought to occur through nonspecific binding on cationic sites on the plasma membrane and their subsequent endocytosis (Chithrani et al., 2006; Verma and Stellacci, 2010). Our results are also consistent with the study of Chithrani et al. (2006) who postulated that serum proteins bind to the surface of citratestabilized gold NPs, producing a more stable gold NP-protein complex, capable of interacting with cell surface receptors. During the transportation process, a process by which cells communicate and internalize extracellular contents and solid materials, foreign materials entered the cells by the invagination of a small portion of the plasma membrane, and then invaginated part pinched off to form a new intracellular vesicle. Observed AgNPs internalization could be as a result the aggregation behaviour of citrate-coated AgNPs in the CCM (see Table 1). Salmaso et al. (2009) have showed an increase in NP uptake upon aggregation, whereas Chithrani and Chan (2007) have reported that 14-nm transferrin-coated nanoparticles were only taken up when clustered in groups of at least six particles. Many factors, such as membrane stretching and membrane's bending energy, should be 
concerned in elucidating the mechanism of NP cellular uptake. The cellular uptake, i.e. how fast and how many NPs are taken up by the cell, can be considered only as a result of competition between the thermodynamic driving force for wrapping and the receptor diffusion kinetics (Chithrani and Chan, 2007). The thermodynamic driving force refers to the amount of free energy required to drive the NPs into the cell whereas the receptor diffusion kinetics refer to the kinetics of recruitment of receptors to the binding site (Chithrani and Chan, 2007). Gao et al. (2005) have suggested that larger NPs would have the faster wrapping time and the receptor-ligand interaction can produce enough free energy to drive the NPs into the cell. For the smaller NPs to go in, they must be clustered together, because their docking will not produce enough free energy to completely wrap the NPs on the surface of the membrane (Gao et al., 2005).

To visualize the uptake process of AgNPs and their intracellular distribution, we employed TEM analyzes of control Pk15 cells and cells treated with 10 and $50 \mathrm{mg} \mathrm{I}^{-1}$ AgNP. There were no visible abnormalities in the control cells, whereas AgNP-treated cells had taken up large numbers of aggregated AgNPs (Fig. 3A). After incubation with 10 or $50 \mathrm{mgl}^{-1}$ AgNP for $24 \mathrm{~h}$, the majority of the aggregates were localized in membrane-bound structures, i.e. lysosomes. Some aggregates were also found in early endosomes, identifiable because they were surrounded by a membrane and had an electron lucent content with respect to the lysosomes (Fig. 3A-D.). Their diameter of over $500 \mathrm{~nm}$ speaks for macropinocytosis as an uptake mechanism (Brandenberger et al., 2010; Pritz et al., 2013). In accordance with other reports on intravesicular particle localization (Brandenberger et al., 2010 and references therein), our findings also indicate that different endocytotic mechanisms (e.g. clathrin- or caveolin-mediated endocytosis) are responsible for the observed intravesicular AgNP localization. A functional characterization of all vesicle types for the quantitative evaluation was not possible on the TEM level. Some additional aggregates of AgNPs also appeared to be situated freely in the cytoplasm, so direct uptake without the formation of endosomes could also take place (Fig. 3B-C.). However, we could not detect any AgNP adsorbed on the plasma membrane. The nanoparticles in aggregates were loosely arranged and individual particles could still be recognized. Energy- dispersive X-ray spectroscopy (EDX) confirmed that the extraand intracellular particles contained silver (Fig. 4). Outside the cells, AgNPs were frequently clustered next to membrane ruffles (Fig. 3D). EDX scans showed very interesting results concerning the elemental composition of AgNP clusters. There was always sulfur associated with the AgNPs, both inside and outside of the cells, whereas no sulfur peak was observed in the EDX scan of as-synthesized and purified AgNPs (Fig. S3 given in Supporting Information). It is known that $\mathrm{Ag}$ forms strong complexes with many inorganic and organic ligands commonly present in biological environments (Choi et al., 2009; McShan et al., 2014). These complexes may undergo rapid exchange, but it appeared that S-ligands are the final thermodynamic sink for Ag (Choi et al., 2009). Results shown in Fig. 4. clearly indicate that AgNPs interfere with cellular S-containing compounds such as metallothionein or glutathione.

No AgNPs were observed in the mitochondria or the nucleus, which is an indication that the AgNPs were not able to breach the double-membrane organization. The ability of NP for free diffusion through nuclear pore complexes is associated with their small size (AshaRani et al., 2009) but in our case AgNPs observed in the cells were situated in dense aggregates, often larger than $200 \mathrm{~nm}$ (Fig. 3A-D) and this could have prevented them diffusing through the pores of the nuclei.

\section{Cell Viability}

It is expected that the biokinetics of NPs, which is measured as the rate of NP uptake, intracellular distribution and exocytosis, contribute tremendously to their toxicity, so we performed a cell viability assay by means of the MTT test to evaluate the possible toxicological effect of AgNP taken up by the Pk15 cells (Fig. 5). For controls, we used both untreated cells and cells treated with the UPW added to CCM at an amount equal to the volume of added AgNPs suspension in treatments. Cytotoxicity studies are often limited by the fact that the interferences of NPs with cell viability assays remained unexplored in most cases. In the cases of existing interferences between NPs and the reagents used in the particular in vitro toxicity assay, results could be false positive or false negative. Possible
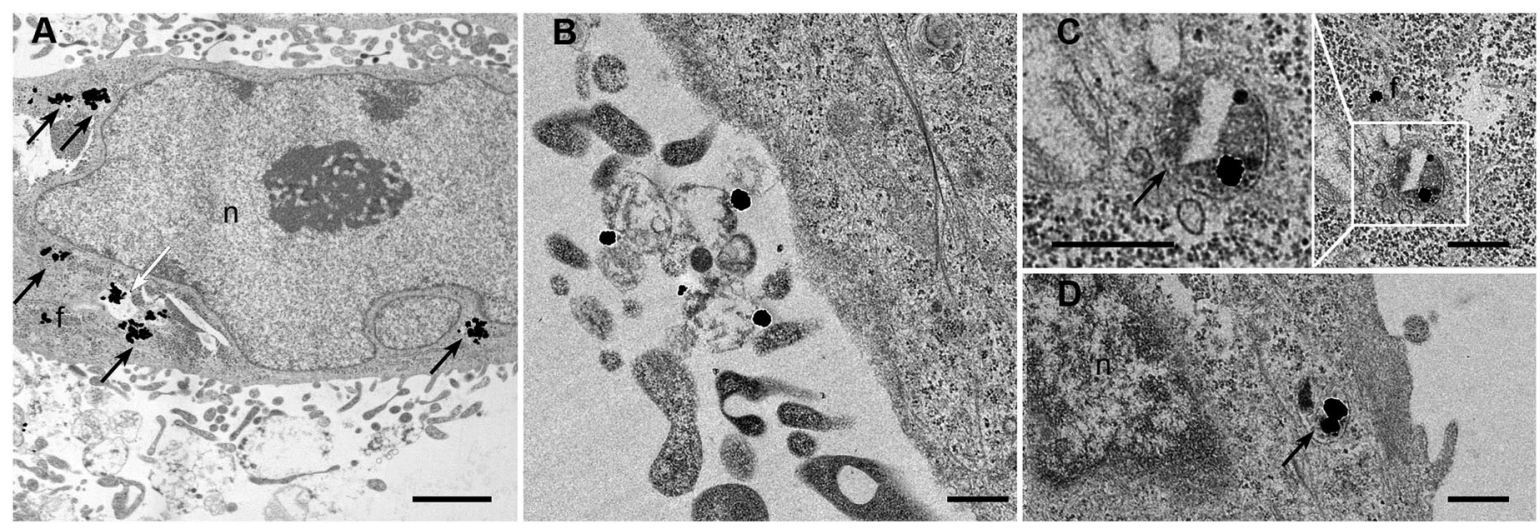

Figure 3. Transmission electron microscopy (TEM) micrographs showing the silver nanoparticles (AgNP) distribution in Pk15 cells. A scanning transmission electron microscopy (STEM) overview of a cell containing an early endosome (white arrow) and several lysosomes (black arrow) filled with aggregated AgNPs. f free AgNPs. B-D: Bright field images. B: AgNPs situated in the medium close to cellular processes. C and D: examples for lysosomes containing AgNPs. The black arrows point to the lysosomes and f signifies free AgNPs. Scale bars: $2 \mu \mathrm{m}$ in A, $500 \mathrm{~nm}$ in B-D. 


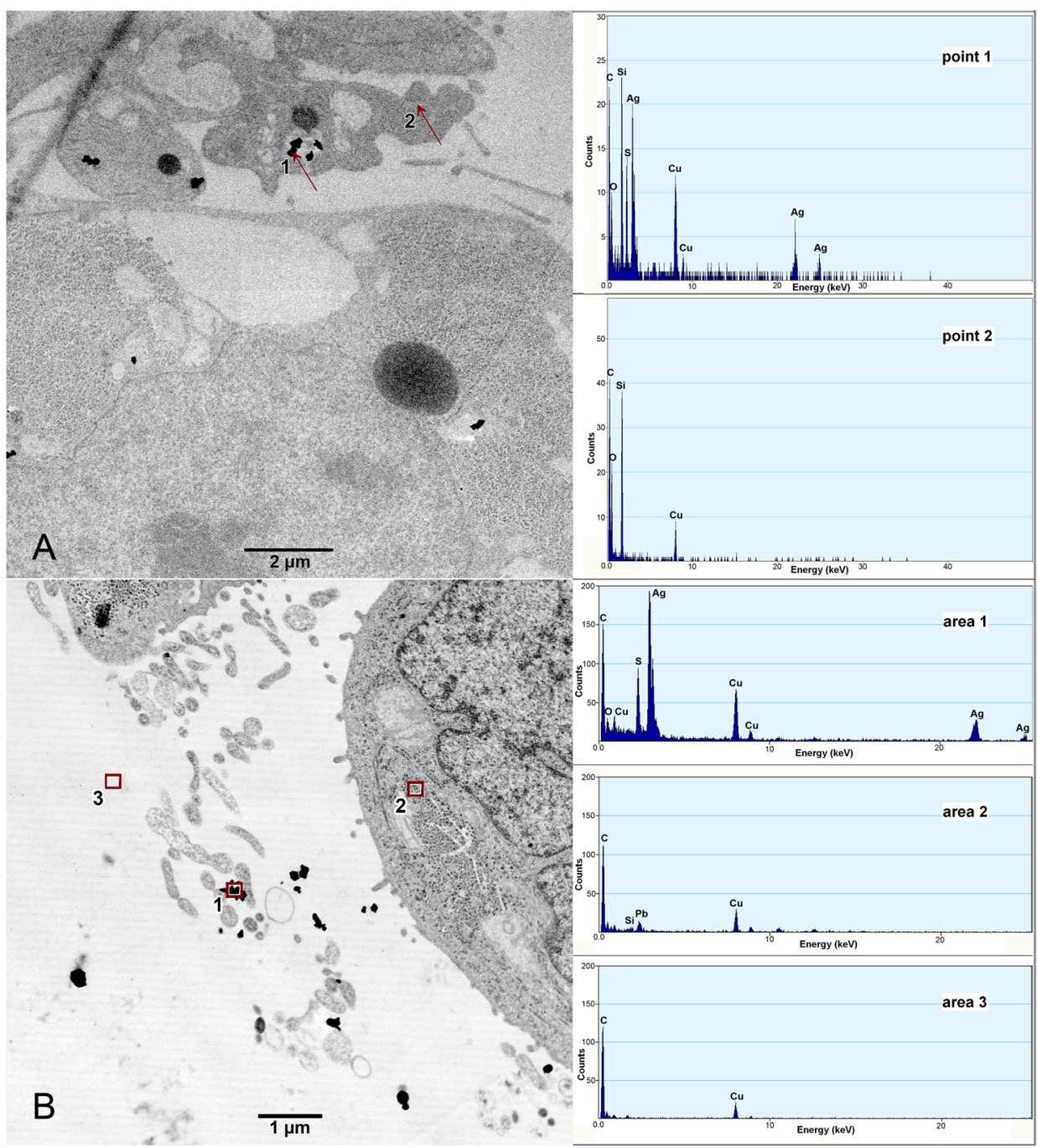

Figure 4. Energy-dispersive $X$-ray spectroscopy (EDX) analyzes of nanoparticles situated in lysosomes ( $A$, point 1$)$ and in the medium (B, area 1$)$ demonstrate that these particles contain silver. Control spectra of the cytoplasm (A, point 2, B, area 2$)$ and the medium surrounding the cells $(B$, area 3 ) demonstrate that these areas do not contain silver.

interactions from particles include particle optical properties and chemical reactions between the particles and the assay compounds (Holder et al., 2012). In order to determine if ionic or nano forms of silver interfere with the MTT assay, we tested the possible reactions of $\mathrm{Ag}^{+}$and $\mathrm{AgNP}$ with the tetrazolium compound and the formazan molecule under cell-free condition. The ionic form of silver did not cause an effect at any concentration as can be seen from Fig. 5. In contrast, AgNPs reacted with $\mathrm{MTT}$ generating formazan under cell-free conditions in a concentration-dependent manner (Fig. 6). Silver nanoparticles were found to interfere with the MTT assay at a concentration of $50 \mathrm{mgl}^{-1}$ or higher. Thus, the MTT assay is only valid for the toxicity assessment of particles present in the testing media at concentrations that do not reduce the MTT. During the MTT assay protocol, the medium containing AgNPs was removed prior to the addition of the MTT solution. Therefore, only AgNPs absorbed into the cells or adsorbed on the cell surface may interact with MTT or formazan. The amount of silver found in Pk15 cells was less than $15 \mathrm{mgl}^{-1}$ after treatment with the highest AgNP concentration (Fig. 2.). Therefore, the MTT results presented in Fig. 4 are unaffected by the interferences with AgNPs or silver ions and the MTT assay was an effective tool in evaluating the toxicity effects of $\mathrm{Ag}^{+}$or citrate coated AgNP on Pk15 cells.

Both forms of silver, nano and ionic, decreased the number of viable Pk15 cells after $24 \mathrm{~h}$ in a dose-dependent manner (Fig. 5). In spite of significant uptake into the cells (Fig. 2), AgNPs had only insignificant toxicity at concentrations lower than $25 \mathrm{mg} \mathrm{I}^{-1}$, whereas $\mathrm{Ag}^{+}$exhibited a significant decrease in cell viability at one-fifth of this concentration (Fig. 5). The decrease in cell viability was $32 \%$ after $24-\mathrm{h}$ exposure to $25 \mathrm{mg} \mathrm{l}^{-1}$ AgNPs and $70 \%$ after $24-\mathrm{h}$ exposure to the same concentration of $\mathrm{Ag}^{+}$. After the treatment of Pk15 cells with the highest AgNP concentration of $75 \mathrm{mg} \mathrm{l}^{-1}$, the viability decreased by $54 \%$ after $24 \mathrm{~h}$, whereas the same extent of decrease was induced by treatment with $10 \mathrm{mgl}^{-1} \mathrm{Ag}^{+}$. These results clearly show that the ionic form of silver had a greater toxicity to mammalian kidney cells compared with the nano form, which agrees with previous studies (Lok et al., 2007; Liu and Hurt, 2010).

Another interesting hypothesis could be drawn from the results presented in Fig. 5. Namely, citrate-coated AgNPs were efficiently internalized reaching a saturation at $50 \mathrm{mg} \mathrm{ml}^{-1}$, 


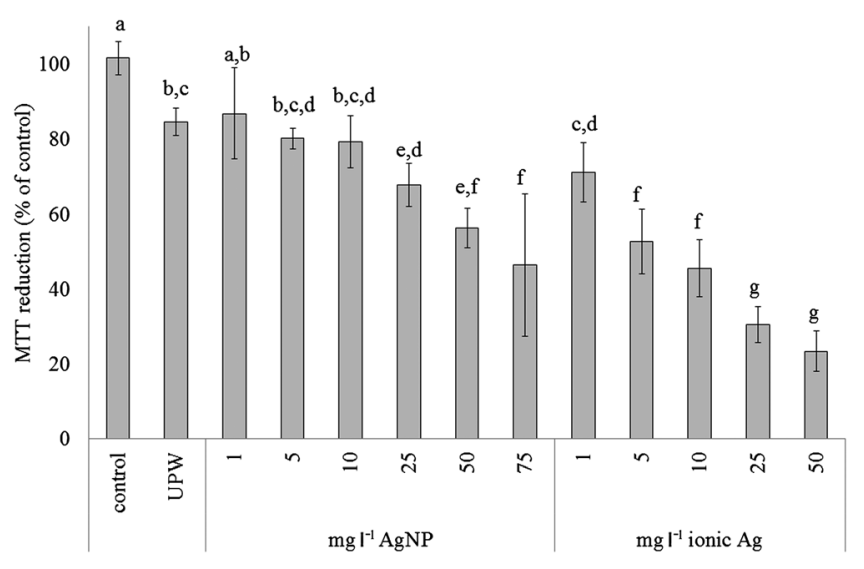

Figure 5. Effect of ionic $\mathrm{Ag}$ and citrate-coated silver nanoparticles (AgNPs) on the cell viability measured by the MTT reduction assay. PK15 cells were exposed to different concentrations, given in $\mathrm{mg} \mathrm{I}^{-1}$, of ionic $\mathrm{Ag}$ and AgNPs for $24 \mathrm{~h}$. Control experiments were done in nanoparticle- or silver ion-free exposure media and with the addition of ultrapure water (UPW). The data for cell viability, expressed as the mean of three independent experiments conducted in five replicates, were calculated as percentages of the values measured in control cells. Error bars represent standard deviations. Different letters denote significant differences between the treatments $(P<0.01)$.

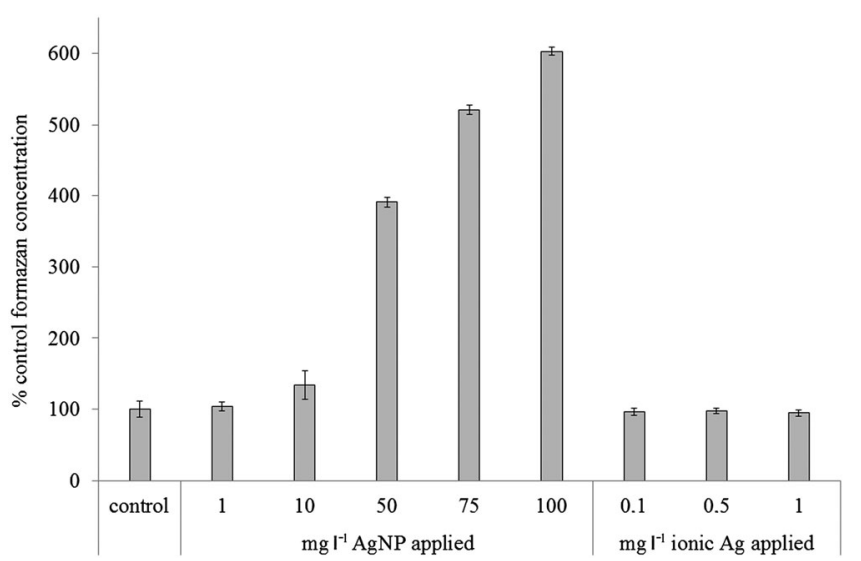

Figure 6. Interferences of the nano and ionic form of Ag with the MTT assay. Potential of $\mathrm{Ag}$ to reduce MTT were determined by incubating MTT with different concentrations of the ionic Ag or citrate-coated silver nanoparticles (AgNPs) in cell-free conditions for $3 \mathrm{~h}$ and measuring the formazan concentration afterwards. The data are expressed as the mean of five replicates and error bars represent standard deviations.

whereas cell viability was substantially decreased. Therefore, impaired cell function could be the reason for the observed plateau in AgNP uptake above $50 \mathrm{mg} \mathrm{ml}^{-1}$. Strikingly, when incubated in the $\mathrm{Ag}^{+}$solution, the uptake showed a similar saturation between 50 and $100 \mathrm{mgl}^{-1}$. Although the treatment with $10 \mathrm{mgl}^{-1} \mathrm{Ag}^{+}$decreased cell viability by more than $50 \%$ after $24 \mathrm{~h}$ (Fig. 5), detected Ag content increased significantly above this concentration and could be the artefact of analytical method. During the sample preparation for ICPMS analyzes, treated cells were washed with PBS, detached from the culture plates using a trypsin and then collected. However, a high amount of $\mathrm{Ag}^{+}$from culture medium might be adsorbed on extracellular membrane surface of damaged cells treated with
50 and $100 \mathrm{mg} \mathrm{I}^{-1} \mathrm{Ag}^{+}$. The ICPMS method used for quantification of Ag uptake does not distinguish absorbed in the cell from adsorbed Ag content on the cell surface.

An important question in the elucidation of the mechanism of action of NPs in living systems is whether toxicity is due to the nano form itself or is related to ions released by the partial oxidation of metallic NPs (Yu et al., 2013). Because the release of $\mathrm{Ag}^{+}$from AgNPs was very low, our results (presented in Table 1 and Fig. 5) indicate that silver is toxic at nanoscale dimension. Moreover, stability experiments showed a decreased level of $\mathrm{Ag}^{+}$in CCM compared with UPW (Table 1), whereas the level of $\mathrm{Ag}^{+}$released in CCM from the highest concentration of AgNP applied in the cell viability experiments was not sufficient to provoke significant toxicity in Pk15 cells when administered to cells in the form of silver ions. However, one may argue that the intracellular dissolution of AgNPs cannot be excluded. After intracellularization of AgNPs, $\mathrm{Ag}^{+}$ ions may dissolve in the lysosomes of the cells. We were not able to detect such a transformation of AgNPs. Similar results have been reported by Powers et al. (2011) who proved that nanosilver acts biologically as NPs and not as a source of silver ions.

\section{DNA Damage}

To understand whether silver NMs induce genotoxicity in Pk15 cells, the alkaline comet assay was used to detect possible DNA damages caused by exposure to AgNPs and the results were compared with that of $\mathrm{Ag}^{+}$. Recent studies on mammalian cell lines reported genotoxicity induced by silver nanoparticles (De Lima et al., 2012; Kim et al., 2010; Suliman et al., 2013). Since DNA damage may favor cancer development or fertility impairment, such results raise concern about the safety of NMs. The alkaline comet assay is a sensitive method able to detect a wide variety of DNA damage such as DNA single-strand breaks, double-strand breaks, DNA-DNA/DNA-protein cross-links, oxidatively induced alkaline damages, alkali-labile sites and sites undergoing DNA repair (Tice et al., 2000; Kassie et al., 2000). A comet-like tail implies the presence of a damaged DNA strand that lags behind when electrophoreses was done with an intact nucleus. The length of the tail increases with the extent of DNA damage. Tail length parameters of control DNA were compared with treated cells, and the extent of damage was assessed. Dosedependent damage to DNA was observed after treatment of the cells with both $\mathrm{Ag}^{+}$and AgNP (Table 2). The Comet assay was carried out with AgNP in the concentration range from 1 to $100 \mathrm{mgl}^{-1}$, whereas only a single $\mathrm{Ag}^{+}$concentration $\left(1 \mathrm{mgl}^{-1}\right)$ was used. After the 24-h treatment, a significant increase in tail length was observed upon exposure to $1 \mathrm{mgl}^{-1} \mathrm{Ag}^{+}$and $10 \mathrm{mgl}^{-1} \mathrm{AgNP}$ or higher compared with the control cells $(P<0.05)$. A longer exposure produced more severe DNA damages considering both comet tail parameters measured (Table 2). After the 48-h treatment, an even lower concentration of AgNP $\left(5 \mathrm{mg} \mathrm{l}^{-1}\right)$ induced a significant increase in tail length in comparison to controls. However, a significant increase in tail intensity was observed after the 24-h treatment with $50 \mathrm{mg} \mathrm{I}^{-1}$ or higher levels of AgNP and after the 48-h treatment with $25 \mathrm{mgl}^{-1}$ or higher levels of AgNP compared with the control. After treatment with $1 \mathrm{mgl}^{-1} \mathrm{Ag}^{+}$, a significant difference in tail intensity compared with the control was observed only after $48 \mathrm{~h}$. 


\begin{tabular}{|c|c|c|c|c|c|}
\hline \multirow[t]{2}{*}{ Exposure time } & \multirow[t]{2}{*}{ Treatment } & \multicolumn{2}{|c|}{ Tail length $(\mu \mathrm{m})$} & \multicolumn{2}{|c|}{ Tail intensity } \\
\hline & & Median & Min - Max & Median & Min - Max \\
\hline \multirow[t]{8}{*}{$24 \mathrm{~h}$} & Control & 26.12 & $15.83-41.67$ & 3.35 & $0-32.84$ \\
\hline & $1 \mathrm{mgl}^{-1} \mathrm{Ag}^{+}$ & $31.67^{*}$ & $18.75-59.17$ & 5.41 & $0-33.78$ \\
\hline & $1 \mathrm{mgl}^{-1} \mathrm{AgNP}$ & 30.42 & $16.67-48.75$ & 5.25 & $0-92.72$ \\
\hline & $5 \mathrm{mgl}^{-1} \mathrm{AgNP}$ & 30.42 & $17.50-48.75$ & 5.17 & $0-45.34$ \\
\hline & $10 \mathrm{mgl}^{-1} \mathrm{AgNP}$ & $34.17^{*}$ & $20.00-55.42$ & 6.51 & 0-99.91 \\
\hline & $25 \mathrm{mgl}^{-1} \mathrm{AgNP}$ & $33.33^{*}$ & $19-17.51 .25$ & 9.53 & $0-44.64$ \\
\hline & $50 \mathrm{mgl}^{-1} \mathrm{AgNP}$ & $36.25^{*}$ & $17.92-57.92$ & $8.62^{*}$ & $0-98.80$ \\
\hline & $75 \mathrm{mgl}^{-1} \mathrm{AgNP}$ & $50.42^{*}$ & $22.08-82.50$ & $11.79 *$ & $0.06-52.23$ \\
\hline \multirow[t]{8}{*}{$48 \mathrm{~h}$} & Control & 37.07 & $22.50-72.50$ & 6.56 & $0.02-34.93$ \\
\hline & $1 \mathrm{mgl}^{-1} \mathrm{Ag}^{+}$ & $47.08^{*}$ & $21.67-88.75$ & $6.53^{*}$ & $0-42.63$ \\
\hline & $1 \mathrm{mgl}^{-1} \mathrm{AgNP}$ & 27.50 & $21.67-86.67$ & 9.51 & $0-48.63$ \\
\hline & $5 \mathrm{mgl}^{-1} \mathrm{AgNP}$ & $42.50^{*}$ & $22.92-86.67$ & 9.93 & $0.06-99.78$ \\
\hline & $10 \mathrm{mgl}^{-1} \mathrm{AgNP}$ & $45.00^{*}$ & $24.17-116.67$ & 17.79 & $0.03-80.16$ \\
\hline & $25 \mathrm{mgl}^{-1} \mathrm{AgNP}$ & $58.33^{*}$ & $27.50-117.08$ & $15.66^{*}$ & $0.01-68.77$ \\
\hline & $50 \mathrm{mgl}^{-1} \mathrm{AgNP}$ & $55.21^{*}$ & $25.00-110.00$ & $17.42^{*}$ & $0.51-67.82$ \\
\hline & $75 \mathrm{mgl}^{-1} \mathrm{AgNP}$ & $64.17^{*}$ & $30.83-114.58$ & $11.89^{*}$ & $0.01-57.60$ \\
\hline
\end{tabular}

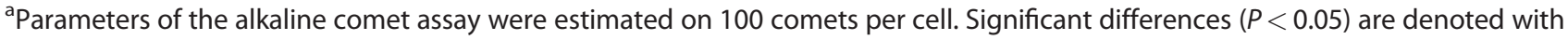
* as compared with the control.

The differences in the response of the comet tail and tail intensity values to $\mathrm{AgNP}$ or $\mathrm{Ag}^{+}$concentration could be explained by the theory of comet tail formation. During electrophoresis, DNA does not migrate by itself but only its relaxed loops and damaged fragments. The tail of the comet is the result of the migration of relaxed DNA loops and fragments (smaller or larger) that are pulled by the electric field to a limited distance from the core. The length of these loops determines the length of the comet tail. As tail intensity indicates the number of DNA breaks, it is assumed that the tail intensity rather than tail length is really increased beyond some critical amount of damage (Collins et al., 1997). Therefore, our results imply that a rather high concentration of AgNP is able to induce genotoxicity in Pk15 cells. These concentrations are several orders of magnitude higher than those occurring in air and water environments (Kumar, 2006). However, as the internal kinetics of NPs has not been elucidated, the local concentration in tissues might reach a higher level as the result of accumulation. As the physicochemical properties of AgNPs such as particle size, particle agglomeration and dispersibility significantly influence the degree and actions of AgNPs, further research is required to assess the effects of these variables on their toxicity.

\section{Conclusion}

We showed that the use of a simple in vitro model with end points that reveal a general mechanism of toxicity can be the basis for assessing the potential risk of NM exposure. A particular cell line (Pk15) has been evaluated and proved for its ability for safety evaluation of metal-based NM. The present study elucidated that AgNPs were taken up by mammalian kidney cells mainly through endocytosis and induced dose-dependent toxicity. Although the ionic form of silver showed greater toxicity on Pk15 cells, the cytotoxic and genotoxic effects of nanosilver were clearly identified. However, we proved that AgNPs is toxic to mammalian cells at very high doses, i.e. only in cases when specific organs accumulated nanosilver. The present study also addressed the stability of AgNPs in biological media and their interferences with the in vitro assay: aspects that are usually overlooked in nanotoxicology. Our study pointed to the need for increased attention and further investigation regarding potential exposure and ultimate risk for metal-based NMs.

\section{Acknowledgments}

We thank Dr Ivan Sabolić for valuable discussions.

\section{Funding Sources}

This work was financially supported by the Grants No. 0220222148-2137 and 022-0222148-2135 (Ministry of Science, Education and Sports of the Republic of Croatia), and by the bilateral Austrian-Croatian project No. WTZ-Hr04/2012.

\section{Conflict of Interest}

The authors declare no competing financial interest.

\section{References}

AshaRani PV, Kah Mun GL, Prakash Hande M, Valiyaveettil S. 2009. Cytotoxicity and genotoxicity of silver nanoparticles in human cells. ACS Nano 3: $279-290$.

Auffan MV, Rose J, Wiesner MR, Bottero J-Y. 2009. Chemical stability of metallic nanoparticles: a parameter controlling their potential cellular toxicity in vitro. Environ. Pollut. 157: 1127-1133. 
Behra R, Sigg L, Clift MJD, Herzog F, Minghetti M, Johnston B, Petri-Fink A, Rothen-Rutishauser B. 2013. Bioavailability of silver nanoparticles and ions: from a chemical and biochemical perspective. J. R. Soc. Interface 10: 20130396. DOI: 10.1098/rsif.2013.0396.

Benn TM, Westerhoff P. 2008. Nanoparticle silver released into water from commercially available sock fabrics. Environ. Sci. Technol. 42: 4133-4139.

Brandenberger C, Mühlfeld C, Ali Z, Lenz A-G, Scmid O, Parak WJ, Gehr P, Rothen-Rutishauser B. 2010. Quantitative evaluation of cellular uptake and trafficking of plain and polyethylene glycol-coated gold nanoparticles. Small 6: 1669-1678.

Bury NR, Wood CM. 1999. Mechanism of branchial apical silver uptake by rainbow trout is via the proton-coupled $\mathrm{Na}^{+}$channel. Am. J. Physiol. Regul. Integr. Comp. Physiol. 277: R1385-R1391.

Cañamares MV, Garcia-Ramos JV, Sanchez-Cortes S, Castillejo M, Oujja M. 2008. Comparative SERS effectiveness of silver nanoparticles prepared by different methods: A study of the enhancement factor and the interfacial properties. J. Colloid Interface Sci. 326: 103-109.

Castellini C, Ruggeri S, Mattioli S, Bernardini G, Macchioni L, Moretti E, Collodel G. 2014. Long-term effects of silver nanoparticles on reproductive activity of rabbit buck. Syst. Biol. Reprod. Med. 60: 143-150.

Chithrani BD, Ghazani AA, Chan WC. 2006. Determining the size and shape dependence of gold nanoparticle uptake into mammalian cells. Nano Lett. 6: 662-668.

Chithrani BD, Chan WCW. 2007. Elucidating the mechanism of cellular uptake and removal of protein-coated gold nanoparticles of different sizes and shapes. Nano Lett. 7: 1542-1550.

Choi O, Clevenger TE, Deng B, Surampalli RY, Ross JL, Hu Z. 2009. Role of sulphide and ligand strength in controlling nanosilver toxicity. Water Res. 43: 1879-1886.

Christian P, Von der Kammer F, Baalousha M, Hofmann T. 2008. Nanoparticles: preparation properties and behavior in environmental media. Ecotoxicology 17: 326-343.

Cohen MS, Stern JM, Vanni AJ, Kelley RS, Baumgart E, Field D, Libertino JA, Summerhayes IC. 2007. In vitro analysis of a nanocrystalline silver-coated surgical mesh. Surg. Infect. (Larchmt.) 8: 397-404.

Collins AR, Dobson VL, Dusinska M, Kennedy G, Stetina R. 1997. The comet assay: what can it really tell us? Mutat. Res. 375: 183-193.

Cronholm P, Karlsson HL, Hedberg J, Lowe TA, Winnberg L, Elihn K, Wallinder IO, Moller L. 2013. Intracellular uptake and toxicity of Ag and $\mathrm{CuO}$ nanoparticles: a comparison between nanoparticles and their corresponding metal ions. Small 9: 970-982.

De Lima R, Seabra AB, Durán N. 2012. Silver nanoparticles: a brief review of cytotoxicity and genotoxicity of chemically and biogenically synthesized nanoparticles. J. Appl. Toxicol. 32: 867-869.

Dziendzikowska K, Gromadzka-Ostowska J, Lankoff A, Oczkowski M, Krawczyńska A, Chwastowska J, Sadowska-Bratek M, Chajduk E, Wojewódzka M, Dušinská M, Kruszewski M. 2012. Time-dependent biodistribution and excretion of silver nanoparticles in male Wistar rats. J. Appl. Toxicol. 32: 920-928.

Farkas J, Christian P, Gallego-Urrea JA, Roos N, Hassellov M, Tollefsen KE, Thomas KV. 2011. Uptake and effects of manufactured X nanoparticles in rainbow trout (Oncorhynchus mykiss) gill cells RID F-3693 2010. Aquat. Toxicol. 101: 117-125.

Fraga S, Faria $H$, Soares ME, Duarte JA, Soares L, Pereira E, CostaPereira C, Teixeira JP, De Lourdes Bastos M, Carmo H. 2013. Influence of the surface coating on the cytotoxicity, genotoxicity and uptake of gold nanoparticles in human HepG2 cells. J. Appl. Toxicol. 33: 1111-1119.

Gao H, Shi W, Freund LB. 2005. Mechanics of receptor-mediated endocytosis. Proc. Natl. Acad. Sci. U. S. A. 102: 9469-9474.

Hinderliter PM, Minard KR, Orr G, Chrisler WB, Thrall BD, Pounds JG, Teeguarden JG. 2010. ISDD: A computational model of particle sedimentation, diffusion and target cell dosimetry for in vitro toxicity studies. Part. Fibre Toxicol. 7: 36.

Holder AL, Goth-Goldstein R, Lucas D, Koshland CP. 2012. Particleinduced artifacts in the MTT and LDH viability assays. Chem. Res. Toxicol. 25: 1885-1892.

Kassie F, Parzefall W, Knasmuller S. 2000. Single cell gel electrophoresis assay: a new technique for human biomonitoring studies. Mutat. Res. 463: 13-31.

Kim YJ, Yang SI, Ryu JC. 2010. Cytotoxicity and genotoxicity of nano-silver in mammalian cell lines. Mol. Cell. Toxicol. 6: 119-125.

Kim YS, Kim JS, Cho HS, Rha DS, Kim JM, Park JD, Choi BS, Lim R, Chang HK, Chung YH, Kwon IH, Jeong J, Han BS, Yu IJ. 2008.
Twenty-eight-day oral toxicity, genotoxicity, and gender-related tissue distribution of silver nanoparticles in Spraque-Dawley rats. Inhal. Toxicol. 20: 575-583.

Kumar C. 2006. Nanomaterials-Toxicity, Health and Environmental Issues. Wiley-VCH Verlag GmbH \& Co.: Weinheim.

Lee HY, Park HK, Lee YM, Kim K, Park SB. 2007. A practical procedure for producing silver nanocoated fabric and its antibacterial evaluation for biomedical applications. Chem. Commun. (Cambridge, UK) 28: 2959-2961.

Lee PC, Meisel D. 1982. Adsorption and surface-enhanced Raman of dyes on silver and gold sols. J. Phys. Chem. 86: 3391-3395.

Lee J, Peña MM, Nose $Y$, Thiele DJ. 2002. Biochemical characterization of the human copper transporter Ctr1. J. Biol. Chem. 277: 4380-4387.

Leitinger G, Pabst MA, Kral K. 2000. Gold toning preserves integrity of silver enhanced immunogold particles during osmium tetroxide treatment for demonstration of a biogenic amine. Brain Res. Protocol. 5: 30-38.

Liu JY, Hurt RH. 2010. Ion release kinetics and particle persistence in aqueous nano-silver colloids. Environ. Sci. Technol. 44: 2169-2175.

Liu W, Wu Y, Wang C, Li HC, Wang T, Liao CY, Cui L, Zhou QF, Yan B, Jiang GB. 2010. Impact of silver nanoparticles on human cells: effect of particle size. Nanotoxicology 4: 319-330.

Lok CN, Ho CM, Chen R, He QY, Yu WY, Sun H, Tam PKH, Chiu JF, Che CM. 2007. Silver nanoparticles: Partial oxidation and antibacterial activities. J. Biol. Inorg. Chem. 12: 527-534.

McShan D, Ray PC, Yu H. 2014. Molecular toxicity mechanism of nanosilver. J. Food Drug Anal. 22: 116-127.

Mosmann J. 1983. Rapid colorimetric assay for cellular growth and survival: application to proliferation and cytotoxicity assays. J. Immunol. Methods 65: 55-63.

Nanotechnology Consumer Product Inventory Wesbsite. 2007. Woodraw Wilson International Center for Scholars http://www.nanotechproject. org/inventories/consumer/ [10 May 2014].

Powers CM, Badireddy AR, Ryde IT, Seidler FJ, Slotkins TA. 2011. Silver nanoparticles compromise neurodevelopment in PC12 cells: Critical contributions of silver ion, particle size, coating and composition. Environ. Health Perspect. 119: 37-44.

Pritz CO, Bitsche M, Salvenmoser W, Dudás J, Scrrott-Fischer A, Glueckert R. 2013. Endocytic trafficking of silica nanoparticles in a cell line derived from the organ of Corti. Nanomedicine 8: 239-252.

Rabolli V, Thomassen LC, Uwambayinema F, Martens JA, Lison D. 2011. The cytotoxic activity of amorphous silica nanoparticles is mainly influenced by surface area and not by aggregation. Toxicol. Lett. 206: 197-203.

Sahu SC, Zheng J, Graham L, Chen L, Ihrie J, Yourick JJ, Sprando RL. 2014. Comparative cytotoxicity of nanosilver in human liver HepG2 and collon Caco2 cells in culture. J. Appl. Toxicol. DOI: 10.1002/jat.2994.

Salmaso $\mathrm{S}$, Caliceti $\mathrm{P}$, Amendola V, Meneghetti $M$, Magnusson JP, Pasparakis G, Alexander C. 2009. Cell up-take control of gold nanoparticles functionalized with a thermoresponsive polymer. J. Mater. Chem. 19: 1608-1615.

Schoonen MAA, Cohn CA, Roemer E, Laffers R, Simon SR, O'Riordan T. 2006. Mineral-induced formation of reactive oxygen species. Rev. Mineral. Geochem. 64: 179-221.

Singh NP, Mc Coy MT, Tice RR, Schneider LL. 1988. A simple technique for quantitation of low levels of DNA damage in individual cells. Exp. Cell Res. 175: 184-191.

Suliman YAO, Ali D, Alarifi S, Harrath AH, Mansour L, Alwasel SH. 2013. Evaluation of cytotoxic, oxidative stress, proinflammatory and genotoxic effect of silver nanoparticles in human lung epithelial cells. Environ. Toxicol. 28. DOI: 10.1002/tox.21880.

Tice RR, Agurell E, Anderson D, Burlinson B, Hartmenn A, Kobayashi $\mathrm{H}_{\text {, }}$ Miyamae Y, Rojas E, Ryu JC, Sasaki YF. 2000. Single cell gel / comet assay: guidelines for in vitro and in vivo genetic toxicology testing. Environ. Mol. Mutagen. 35: 206-221.

Trop M, Novak M, Rodl S, Hellbom B, Kroell W, Goessler W. 2006. Silver-coated dressing acticoat caused raised liver enzymes and argyria-like symptoms in burn patient. J. Trauma: Inj., Infect., Crit. Care 60: 648-652.

Verma A, Stellacci F. 2010. Effect of surface properties on nanoparticlecell interactions. Small 6: 12-21.

Vigneshwaran N, Kathe AA, Varadarajan PV, Nachane RP, Balasubramanya RH. 2007. Functional finishing of cotton fabrics using silver nanoparticles. J. Nanosci. Nanotechnol. 7: 1893-1897. 
Walker M, Parsons D. 2012. The biological fate of silver ions following the use of silver-containing wound care products - a review. Int. Wound J.. DOI: 10.1111/j.1742-481X.2012.01115.x.

Wang Z, Li N, Zhao J, White JC, Qu P, Xing B. 2012. CuO nanoparticle interaction with human epithelial cells: cellular uptake, location, export, and genotoxicity. Chem. Res. Toxicol. 25: 1512-1521.

Yang H, Liu C, Yang D, Zhang H, Xi ZJ. 2009. Comparative study of cytotoxicity, oxidative stress and genotoxicity induced by four typical nanomaterials: the role of particle size, shape and composition. Appl. Toxicol. 29: 69-78.
Yu SJ., Chao JB, Sun J, Yin YG, Liu JF, Jiang GB. 2013. Quantification of the uptake of silver nanoparticles and ions to HepG2 cells. Environ. Sci. Technol. 47: 3268-3274.

Zhang Y, Sun J. 2007. A Study on the bio-safety for nano-silver as antibacterial materials. Chin. J. Med. Instrum. 31: 35-38.

\section{Supporting Information}

Additional supporting information may be found in the online version of this article at the publisher's web site. 